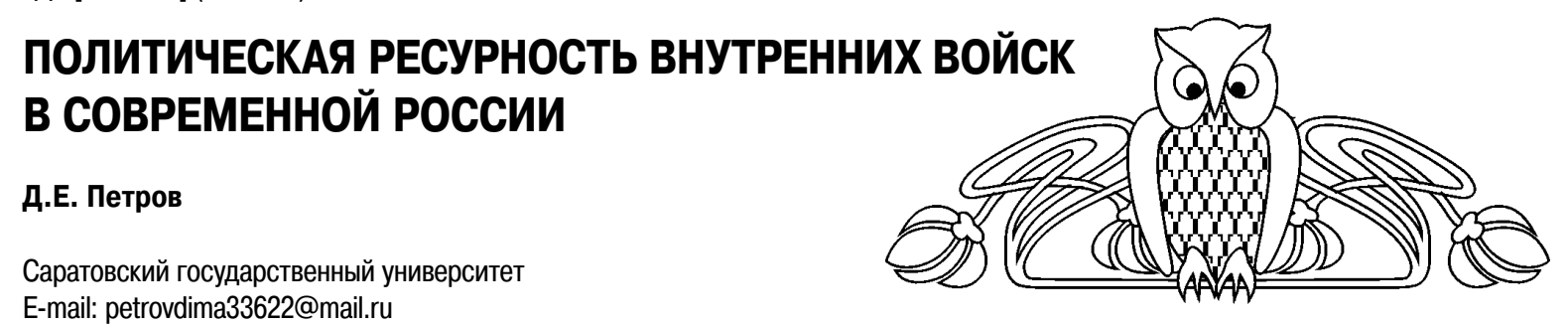

E-mail: petrovdima33622@mail.ru

В статье исследуется политическая ресурсность внутренних войск в современной России. Автор последовательно анализирует специфику функционирования, конкретные политикоресурсные характеристики внутренних войск и делает вывод об их значимости в политических процессах в стране.

Ключевые слова: политическая ресурсность, внутренние войска, силовые структуры.

\section{Political Resources Internal Forces in Modern Russia}

\section{D.E. Petrov}

This article explores the political resources of internal forces in modern Russia. The author successively examines the specifics of the functioning, the resource characteristics of internal forces and make conclusions about their significance in the political process in the country.

Key words: political resources, internal forces, power structures.

Политическая история России и зарубежных стран свидетельствует, что силовые структуры обладают значительной политической ресурсностью инструментального и субъектного характера. Особенно это справедливо для формирований, специально созданных для решения внутриполитических задач. К их числу относятся и внутренние войска $(\mathrm{BB})^{1}$, представляющие собой специальные воинские формирования, предназначенные для силового разрешения внутригосударственных конфликтов, охраны общественного порядка, обеспечения безопасности личности, общества и государства, прав и свобод человека и гражданина от преступных и иных противоправных посягательств ${ }^{2}$.

Присутствие внутренних войск в системе государственной власти обусловлено наличием в мировой политико-административной практике ещё с глубокой древности определённых стандартов силового взаимодействия государства и общества, в том числе: недопущение армии к решению внутриполитических проблем, борьбе с внутренними врагами государства и подавлению гражданских волнений, а также нелетальный характер большинства методов борьбы с внутренними врагами и гражданскими волнениями, в отличие от того инструментального набора, который имеется в распоряжении армии для противодействия агрессорам. Относительно роли внутренних войск в современных условиях в деле борьбы с внутренними врагами, которые могут быть весьма разнообразны и многочисленны, заметим, что в этом измерении эти войска не уникальны - в различных плоскостях противодействовать внутренним врагам уполномочены все силовые структуры, и методы их могут носить самый разнообразный характер, в том числе и иметь летальные последствия.

Специфичность внутренних войск как воинских формирований особого рода проявляется именно в отношении гражданских волнений. Здесь использование армейских частей, не имеющих достаточной политической и специальной подготовки для действий в таких ситуациях, может повлечь за собой определённые осложнения. Во-первых, сам факт обращения штыков армии против своего народа наносит значительный удар по легитимности правящего режима. Во-вторых, военнослужащие армейских частей и подразделений при подавлении массовых беспорядков, особенно если они вызваны реальными несправедливостями государственной политики, могут начать колебаться и даже переходить на сторону участников гражданских волнений. В-третьих, отсутствие у бойцов армейских подразделений специальной подготовки и спецсредств для действия в условиях гражданских волнений не только снижает эффективность мероприятий по подавлению массовых беспорядков, но и подчас приводит к неоправданно большим жертвам среди населения.

Понимание необходимости специальных формирований для борьбы с внутренними волнениями имело место ещё в глубокой древности. В частности, древнекитайский стратег У-Цзы, живший в V-IV вв. до н.э., так обосновывал предназначение вооруженных формирований: «Обычно поднимают войско на войну из-за пяти причин: первое - из-за славы; второе - из-за выгоды; третье - из-за накопившихся обид; четвертое - из-за внутренних беспорядков; пятое - из-за голода. Эти причины, в свою очередь, обусловливают пять видов войск: первое - справедливые войска; второе - насильственные войска; третье - неистовые войска; четвертое - жестокие войска; пятое - мятежные войска». Следовательно, еще в Древнем Китае один из видов войск, «жестокие войска», предназначался для борьбы с «внутренними беспорядками» $3^{3}$.

В современном мире военизированные формирования внутренней направленности существуют практически в каждом государстве, но далеко 
не везде они называются внутренними войсками и могут подчиняться не министру внутренних дел, а министру обороны, или президенту, или находиться под совместным контролем нескольких ведомств. В частности, во Франции аналогом внутренних войск является Национальная жандармерия, в Испании - Гражданская гвардия, в США и большинстве латиноамериканских стран - Национальная гвардия, в Италии - Корпус карабинеров, карабинерами называют силы внутренней безопасности и в Молдове. Название «внутренние войска» распространено на постсоветском пространстве: в бывших республиках СССР и некоторых странах соцлагеря (Польша, Монголия). Национальная гвардия популярна в латиноамериканских странах, развивавшихся под значительным политическим влиянием Соединённых Штатов. Жандармерией принято называть воинские формирования внутренней безопасности не только во Франции, но и в бывших её колониях, а также в странах, где государственное строительство осуществлялось с опорой, в числе прочего, и на французский опыт. Есть и другие наименования внутренних сил безопасности мобильные части полиции постоянной готовности (ФРГ), различные батальоны и полки полиции оперативного назначения и т.д. При этом для облегчения восприятия материала и с учётом особенного внимания, которое мы уделяем развитию этого института именно в России, в данной статье для обозначения военизированных формирований внутреннего предназначения используется единый термин «внутренние войска».

В современной России внутренние войска входят в систему МВД и являются «другими войсками» (согласно ФЗ «Об обороне») 4 , предназначенными для обеспечения безопасности личности, общества и государства, защиты прав и свобод человека и гражданина от преступных и иных противоправных посягательств 5 . Законом на них возложены традиционные для такого рода формирований функции: участие совместно с органами внутренних дел в охране общественного порядка, обеспечении общественной безопасности и режима чрезвычайного положения; участие в борьбе с терроризмом и обеспечении правового режима контртеррористической операции и др. ${ }^{6}$

Выполняемые внутренними войсками функции условно можно разделить на три группы: полицейские (содействие милиции и пограничникам, охрана грузов и объектов и др.), военные (территориальная оборона, борьба с терроризмом и др.) и политические (подавление гражданских волнений и др.). Последняя группа функций прямо в Федеральном законе по понятным причинам не прописана, но от этого не менее важна и является институтообразующей применительно к внутренним войскам. Сугубо военные задачи в связи с напряжённой обстановкой на Северном Кавказе внутренним войскам в последнее время вместе с армией приходилось решать довольно часто, за что их неофициально стали называть «воюющими войсками» ${ }^{7}$. Столь активное использование государством именно военного потенциала внутренних войск имело место, наверное, только в послевоенный период истории СССР, когда части $\mathrm{BB}$ активно привлекались к боевым действиям против НВФ украинских националистов ${ }^{8}$.

Общая численность частей и подразделений внутренних войск в нашей стране составляет около 170 тыс. чел. ${ }^{9}$, в то время как в начале 1990-х гг. их численность была вполне сопоставима с Сухопутными войсками Вооружённых сил России и составляла 304 тыс. чел. Для сравнения, на Украине численность ВВ составляет 33,5 тыс. чел., в Белоруссии - около 11 тыс. чел., в Казахстане - до 25 тыс. чел. Есть внутренние войска в Армении, Азербайджане, Кыргызстане и Туркменистане. Организационно во всех названных странах ВВ входят в структуру МВД. Наряду с внутренними войсками в ряде постсоветских государств создавались национальные (на Украине, в Кыргызстане и Узбекистане) или республиканские гвардии (Казахстан) ${ }^{10}$.

Обозначенное выше сокращение численности можно объяснить сужением функциональной сферы деятельности ВВ в России, с которых в 1998 г. были сняты функциональные обязанности по конвоированию заключённых и охране мест лишения свободы. Также в середине 2000-х гг. большая часть тяжёлого вооружения, в том числе танков, внутренних войск была передана министерству обороны, что объяснили необходимостью оптимизации вооружения этих формирований в соответствии с возложенными на них задачами в изменившихся политико-экономических условиях. Вместе с тем существенно выросла численность специализированных моторизированных воинских частей - подразделений внутренних войск, созданных для содействия милиции в охране общественного порядка в крупных населённых пунктах, что свидетельствует об усилении полицейского компонента в функциональности ВВ.

О политической значимости института внутренних войск в современной России свидетельствует стабильно благополучное их положение в качественном и количественном измерении в сравнении с другими силовыми структурами, а также то гипертрофированное внимание, которые уделяют любым учениям и перемещениям частей и подразделений внутренних войск некоторые представители оппозиции, прогнозируя массовые народные волнения, связанные с последствиями финансового кризиса. Примечательно в этом плане решение о приостановке принятого в 2006 г. Советом безопасности решения о сокращении внутренних войск МВД РФ, в то время как в армии собираются увольнять 205 тыс. офицеров и 140 тыс. прапорщиков и мичманов. Тогда было решено сократить ВВ с примерно 200000 чел. до 140000 к 2011 г., и сейчас эти подчиненные МВД войска, состоящие из отрядов спецназа, частей 
оперативного назначения и частей по охране особо важных объектов, насчитывают, как отмечалось выше, около 170000 чел. Объясняется это решение необходимостью усиленных мер безопасности во время Олимпиады-2014 в Сочи (зачем сокращать, чтобы потом снова восстанавливать). Это официальная версия, а вот представители оппозиционных партий и ряд аналитиков считают, что таким образом власть готовится к грядущим народным волнениям, которые, по их мнению, будут происходить в контексте финансового кризиса ${ }^{11}$.

Вместе с тем сравнительный анализ соотношения численности военизированных формирований внутренней безопасности и Вооружённых сил в России и различных зарубежных странах не даёт нам оснований говорить о гипертрофированном развитии этого института в нашей стране. В частности, численность дореформенной Российской армии составляла 1 млн 120 тыс. чел. ${ }^{12}$, численность внутренних войск - 170 тыс. чел., таким образом, соотношение воинских формирований внутреннего и внешнего применения в Российской Федерации составляет 0,15 . В то время как расчёт аналогичных соотношений (BB/BC) в зарубежных странах, по справочным данным на 2006 г. $^{13}$, дал следующие значения: Иран - 0,1; Италия - 0,58; Йемен - 0,71; Марокко - 0,1; Монголия - 0,14; Пакистан - 0,3; Польша-0,05; Португалия - 0,58; Перу - 0,96; Республика Конго - 0,2; Румыния 0,59; США - 0,31; Турция - 0,29; Франция - 0,41. Политический смысл данного коэффициента понятен: чем больше его значение, тем больше относительная величина военизированных формирований, приготовленных в конкретном государстве для силового решения внутриполитических проблем, в том числе и борьбы с гражданскими волнениями. Цифры показывают, что Россия в деле развития сил внутренней безопасности далеко не лидер. Более благополучные в социальном плане и с точки зрения межнациональной напряжённости значительно меньшие по территории и, что не менее важно, демократичные в глазах мировой общественности Франция и Италия ушли значительно вперёд в организации военизированных формирований для подавления гражданских волнений, что вместе с тем не мешает им считаться эталонами демократии в современном мире.

Значимость института внутренних войск в политических процессах ряда государств ближнего зарубежья можно оценить не только на основе анализа численности, финансирования и полномочий, но и изучая их роль в периоды политических кризисов, в частности, во время т.н. «цветных» революций. На Украине, в Киргизии, в
Грузии исход революционных событий во многом зависел от позиции «силовиков», а военнослужащие внутренних войск (или аналогичных формирований) подолгу не покидали площади и улицы революционных городов ${ }^{14}$.

В целом сегодня внутренние войска характеризуются развитой политической ресурсностью инструментального плана и являются органично встроенным в политическую систему современной России инструментом поддержания общественного порядка и политической стабильности.

\section{Примечания}

1 В данной статье мы при необходимости будем использовать также и общепринятое сокращённое название внутренних войск - ВВ.

2 См.: Попов И.М., Рогалев А.П. Внутренние войска (структуры им подобные) в системе обеспечения внутренней безопасности зарубежных государств (19451997 гг.). М., 1998; Тарасов М.М. Служебно-боевой опыт войск правопорядка // Вестн. Томск. гос. пед. ун-та. 2006. № 11.

3 Сунь-Цзы (У-Цзыз). Трактаты о военном искусстве. M., 2002. C. 46.

4 Федеральный закон от 06.02.1997 № 27-Ф3 (ред. от 30.10.2007) «О внутренних войсках Министерства внутренних дел Российской Федерации» // Рос. газ. 2007. 7 нояб.

5 Федеральный закон от 31.05.1996 № 61-Ф3 (ред. от 26.06.2007) «Об обороне» // Рос. газ. 1996. 6 июня.

6 Там же.

7 См.: Война и мир воюющих войск // Братишка. 2006. № 3 .

8 См.: Климов А.А. Деятельность внутренних войск МВД СССР по обеспечению общественной безопасности на территории Западной Украины в 1944-1953 гг. // Сборник научных статей адъюнктов Военного университета. M., 2005. № 8 .

9 См.: Никольский А. Солдат с дубинкой ещё пригодится // Ведомости. 2008. № 239.

10 См.: Что такое Национальная гвардия // КоммерсантЬ Украина. 2007. № 92; Яиенко Д. Гвардия президента // Профиль. 2007. № 13 и др.

11 См.: Никольский А. Указ. соч.

12 См.: Гольи А. Секретная реформа // Pro et Contra. 2009. № 1(44).

13 См.: Вооруженные силы зарубежных стран (справочные данные) // Зарубежное военное обозрение. 2006. № 2.

14 См.: Зыгарь М. Война и миф. М., 2007; Полтораков А. «Силовые» структуры Украины в контексте «помаранчевой революции» // Wspolczesna Ukraine. Lodz, 2007 и др. 